\title{
The Study on the Entrepreneurship Direction College Music Majors of Inner Mongolia
}

\author{
Hongyan Wang ${ }^{1, \text { a }}$ \\ ${ }^{1}$ The college of music Chifeng University, Chifeng Inner Mongolia 024000 China \\ aemail-wanghongyan323@163.com
}

Keywords: Inner Mongolia; College music professional; Entrepreneurial orientation

\begin{abstract}
In the fierce competition in front, Inner Mongolia university music graduates majoring because of strong professional, employment face is relatively narrow, social demand is small, at the same time also face from key universities, music colleges and non-art music class specialized competition for graduates, the difficult employment problem is more outstanding, therefore, the competitiveness of employment is enhanced, and obtain comparative advantage in the competition to become particularly important. Inner Mongolia colleges and universities need to continuously break through the bottleneck of its development, change the traditional personnel training mode, renewal education idea, innovating teaching content and teaching methods, sets up the entrepreneurial ideas, promote entrepreneurship ability, and should direct docking with the society, to focus on social needs, become passive to active employment entrepreneurship. It is not only for his job creation; at the same time also create more jobs for the society. This article will elaborate the pioneering status quo and direction of college music majors in Inner Mongolia.
\end{abstract}

\section{Introduction}

At present, our country is in economic transition period, for graduate students in colleges and universities, both opportunities and challenges. Under this big background, our country's higher music education should also be subsequently transformation, at any time to adapt to the change of market and society, meet the needs of the present society, for the society develop innovative and entrepreneurial ability of applied music professionals, is a major responsibility of local colleges and universities, but also the era have entrusted to the historical mission of music major education in colleges and universities. Local university which is located at the center of the city, while enjoys a unique resource advantages, has also been great geographic and constraints. As the college enrollment system reform, constantly expand the scale of enrollment in colleges and universities, the local university music graduates employment situation more and more serious. Faced with the problem of employment, many college students to start their own businesses, however, in the present university education mode, the status quo of self-employment is not optimistic, need to relevant departments to intensify reform, create a good employment environment for college students.

\section{The situation of students' difficult employment music education in colleges and universities}

The derailment music teaching and social needs. On the one hand, with the development of spiritual civilization of human society and people's aesthetic ability to ascend, the concert has a wider application development market. On the other hand, in the fierce market competition, music professional college graduates are faced with great employment difficulties. Generally speaking, set the music major education in colleges and universities are divided into five categories, namely the music education, music performance, music, composer and conductor, art management class. Music education class students' employment is the main tendency in school or social power of music education. Music performance classes, student employment tend to enter oneself for an examination professional play music performances and groups; Musicology, composer and conductor theoretical strong, suitable for the study of the theory of the professional; Art management class belongs to the 
rise of applied science in recent years, the employment direction for theatre, theatre company management and culture industry management, etc.

Of course, these are only professional and employment cohesion theory of ideal pattern, in fact, music professional graduates employment and ideal condition is far, far from reaching "non-trace docking", on the contrary, the contradictions and conflicts are intensified. On the one hand, on the other hand is the social demand gap is well couldn't find a job, this phenomenon is more and more become music graduates are faced with the serious contradiction.

The music professional students' employment of their own problems. Students' employment is inseparable with its problem. Due to personal love of music degree, college entrance examination scores of culture, many students have no music specialty "reluctantly" chose music major, enter oneself for an examination of the limitations of blindness and choose cause they didn't consider the problem of employment in the future. And after entering the university, was admitted to the university after the excitement and get rid of the high school study pressure released in full, and with the most students do not love learning, learning atmosphere is loose, lead to a lot of students don't seriously don't study hard, professional knowledge is low, and unproductive, few students thinking about four years later the problem of employment.

\section{The present problems existing university the music major students' entrepreneurial in colleges and universities of Inner Mongolia}

The student to the music professional employment expectations too high. Most parents think that as long as good for children to find a way out, just not hesitate heavy gold to various art exam training of children, so the taller also to the child's future employment expectation return, hope children can become quite accomplished in music wit, however, not all music graduates can enter after leaving school large music production company, most graduates are starting from the most basic music studio creation, and even some music professional students directly gave up the professional, transferred to other industries. In addition, some students for good face of reason, think of entrepreneurship is unable to find work, has a rejection on self-employment.

The graduates cannot bear startup costs. For family condition general graduates, four years of college professional learning has consume most of the money in the home, not only unable to employment after graduation return home, but also to home again to self-employment fund, that, for many graduates have to afford. Although the state corresponding support part of the venture capital, but for the whole process of entrepreneurship, or not enough, so the lack of venture capital, also make part of the music off self-employment for professional graduates.

The curriculum of colleges and universities lack of exercise. Music student during the period of school, but in theory practice learning vocal music class and Musical Instruments, are not under the relevant business training. While most colleges and universities have opened courses about college students' employment guidance, but the pertinence is not strong, on the one hand, the employment guidance course and not close to the relationship between student self-employment, failed to combined with the actual business process, on the other hand, if there is no professional business entrepreneurship guidance teachers, will affect students' understanding and the understanding of entrepreneurship, unable to entrepreneurship practice have a profound experience.

\section{The countermeasures of university music students' entrepreneurial ability training of Inner Mongolia}

The building scientific system of entrepreneurship education. a. The changing employment idea, sets up the pioneering consciousness. Thought is the forerunner of action, Inner Mongolia colleges and universities should actively guide the music professional college students' changing ideas, help students to develop their awareness and diversity of employment ideas. Encourage students to dare to break the traditional, contend with secular, to let students understand business risks and opportunities coexist, dare to innovation, dares to attempt, dares to challenge, the entrepreneurship as an effective way of employment, to start a business to create more employment 
opportunities, change passive to active employment entrepreneurship. Let inspirational entrepreneurial idea thorough popular feeling, makes the students understand that entrepreneurship is a period in the future the trend of The Times in China, was supported and encouraged by the government, is a respected behavior, also is protected by law, choose entrepreneurship can also realize their own dreams, embody self struggle of life value. By analyzing some examples of successful entrepreneurs, let the students choose to feel the meaning of entrepreneurship.

b. Build the entrepreneurship education system, optimize the knowledge structure. To music major education in colleges and universities in Inner Mongolia the entrepreneurship education into the teaching of professional education and culture quality education effectively plan and credit system, establish a multi-level, three-dimensional system of entrepreneurship education courses. To highlight the characteristics of professional at the same time, will venture education organic combination and music professional curriculum system, and entrepreneurship practice activities to effective connection with music professional practice teaching, through the art practice to understand specific connotation of entrepreneurship, through entrepreneurship to further strengthen and consolidate art practice teaching. Art practice builds the platform for entrepreneurship, entrepreneurship in art practice as the carrier, in the process of artistic practice and entrepreneurship to cultivate the students' creative thinking and creative ability. Entrepreneurship is the focus of the applied talents training, music major education in colleges and universities in Inner Mongolia and music professional college students adapt to the needs of society in the new period of necessary skills. Around applied talents in colleges and universities in Inner Mongolia, promote the reform of personnel training mode, adjust the education teaching content, optimizing the structure of knowledge and scientific construction of entrepreneurship education curriculum system.

The create a relaxed business environment. a. Strengthening public opinion guidance, publicity and innovative business ideas. College students' entrepreneurship need good entrepreneurial environment to support the society and colleges and universities. Government and colleges and universities in the aspect of music professional college students' self-employment to strengthen public opinion guidance, change the traditional concept of employment, actively advocating music professional college students self-employment, take the initiative to create jobs. Government through television, newspapers, mobile vehicle, the news media, such as the Internet, the school will through the campus television station, radio, posters, banners, publicity window, exhibition board, the enrollment of college employment website, QQ group, Wechat related way, vigorously promote national policies, laws and regulations, encourage entrepreneurship of college students. As to the application for entrepreneurship of college students can be appropriately simplified industrial and commercial registration procedures, tax breaks and providing small loans, etc. Promote school about entrepreneurship related preferential policies, financial and technical support, etc. As a business foundation for help the college students' entrepreneurship, establish business incubators, to provide expert technical guidance, etc.

b. Hold entrepreneurship training, entrepreneurship technology skills. Holding business knowledge lectures is one of the important measures of the college students' entrepreneurship education in colleges and universities. Through training, aimed at improving music professional college students' consciousness of entrepreneurship and entrepreneurial skills, strengthen the mental capacity to overcome the difficulty and risk awareness, out of the startup blind area. Universities in Inner Mongolia are to fully exploit and make use of all kinds of music education resources, hired outside the shop, school of art and music art exam training, cultural media companies, art kindergarten's boss, business experts, alumni and other successful people, through seminars, on-site report, symposium, experience exchange and so on many kinds of ways, for music professional college students venture to provide technical guidance, training and information transmission, make students with entrepreneurial intention reserves as early as possible and entrepreneurship related theory, policies, regulations and the necessary professional theoretical knowledge.

To set up appropriate entrepreneurial platform. The specialized music professional college students teaching subjects, is exposure to a narrow range of knowledge, the choice of entrepreneurial projects, entrepreneurial small bottleneck. Therefore, colleges and universities in 
Inner Mongolia to build appropriate business platform, provide more entrepreneurial practice opportunities for students, promote the cultivation of students' entrepreneurial interest and ability of the business.

a. The construction of business incubators, provide entrepreneurial practice platform. Inner Mongolia colleges and universities and the local government or some joint construction enterprise which has the function of rolling hatching industrial park, science and technology park, business street, guide and encourage music professional college students access to the park for a startup. Students can set up shop in the park, entrepreneurship, music dance training class, culture media co., school of art, etc., can enjoy the related preferential policies of the state, schools and companies can provide professional and technical guidance, some good outlook can also enjoy the entrepreneurial foundation funds to support key projects.

b. The entrepreneurship practice team established, cultivate team spirit of entrepreneurship. College students' entrepreneurship is for the first time, lack of experience. School is the best to the same music or has a common interest in entrepreneurship students into several groups of business practice. On the one hand, many hands make light work, a few people together to joint venture, can greatly reduce the pressure of personal funds, and enhance ability to resist risks. , on the other hand, should not only reasonable division of labor between team members, and to work together, so that he can consult each other, each other and care, is able to develop the students' team spirit and cooperation spirit, the pioneering teachers can according to their specific project and characteristics of classified guidance, has strong pertinence and effectiveness.

\section{Summary}

The graduates of music major education in colleges and universities in Inner Mongolia self-employment ability, is a reasonable solution to the problem of difficult employment for graduates in music one of the most effective way. Set up the students' consciousness of their own businesses, increase exercise and social entrepreneurship practice, country, school full cooperation and support, can enhance the student's own advantages, enlarge the influence of school education, for the country and social culture and the high quality applied music talents.

\section{References}

[1] Stevenson HH,Jarillo JC.A paradigm of entrepreneurship: entrepreneurial management. Strategic Management Journal. 2012.

[2] Rosemary Athayde.Measuring Enterprise Potential in Young People. Entrepreneurship Theory and Practice. 2013.

[3] Dean A Shepherd,Evan J Douglas,Mark Shanley.New venture survival: Ignorance, external shocks, and risk reduction strategies. Journal of Business. 2012.

[4] Henry Etzkowitz,Marina Ranga,Mats Benner,Lucia Guaranys,Anne Marie Maculan,Robert Kneller.Pathways to the entrepreneurial university: towards a global convergence. Science and Public Affairs. 2013.

[5] Donald F. Kuratko.The Emergence of Entrepreneurship Education: Development, Trends, and Challenges. Entrepreneurship Theory and Practice. 2011.

[6] Jay Mitra,Harry Matlay.Entrepreneurial and vocational education and training: Lessons from Eastern and Central Europe. Industry and Higher Education. 2012. 